\title{
EVALUATION OF THE POLISH OPINION-GIVING MODEL APPLIED BY COURT EXPERTS SPECIALISING IN EXAMINATION OF WRITTEN DOCUMENTS. TENDENCIES FOR CHANGES
}

\begin{abstract}
The publication will present the most important problems related to the model of experts in the field of examination of written documents, which functions in Poland, with particular emphasis on the experts registered on court lists. These lists should be a reliable — and thus helpful — source for the search for and selection of the best expert in a given case. However, they do not serve this function properly. The very level of opinions drafted by experts in the field of handwriting analysis is also an extensively discussed issue. The reasons for this status quo should be perceived, inter alia, in the lack of uniform procedures for carrying out analyses and formulating conclusions in the field of handwriting documents examination, as well as in the lack of a reliable and comprehensive training system for experts in this field of knowledge.
\end{abstract}

Keywords: expert, documents expert examination, expert opinion, documents examination, handwriting analysis

The current legal regulations in force, which lay down the status of entities providing opinions for the purposes of law enforcement agencies and the justice system, have been criticised and defined as incompetent and dangerous for many years, since they may exert negative effects on the parties to the proceedings, and even lead to miscarriages of justice which - as a consequence - may decrease citizens' trust in the justice system. Media reports, as well as research conducted on the basis of the analysis of specific cases, and carried out in the form of questionnaire statements given by the persons who conduct legal proceedings, as well as their participants, display the weight of this issue. ${ }^{1}$

1 See: W. Juchacz, Pomytki sądowe w sprawach o zabójstwa. Studium karno-procesowe, Bydgoszcz 2016; A. Sowa, "Przyczyny pomyłek sądowych", Palestra 2002, no. 1; J. Widacki, A. Dudzińska, "Pomyłki sądowe. Skazania osób niewinnych przez sądy w Polsce", Palestra 2007, 11-12; O. Mazur, "Niesłuszne skazania w Polsce w opinii prokuratorów i policjantów", Palestra 2012, 3-4; 
Considerations of the issues specified in the title of this paper should begin with a reference to the very concept of an expert registered in the court list, which is used by the legislator, as well as in scientific publications. This term is a kind of mental short-cut and may lead to the false belief that a person entered on such a court list is an expert. Nevertheless, according to Polish legal regulations, the status of an expert is obtained at the moment of the person's appointment by a trial body in a certain legal proceeding, pursuant to a decision to admit evidence based on an expert opinion. ${ }^{2}$

For the purposes of this publication, a review of the court lists managed by the Polish Regional Courts in the field of handwriting, technical and linguistic analysis of documents was carried out. Having studied them, one can conclude that there are plenty of experts in documents examination. The current number of entries on the court lists in this area of study is just over $700 ;{ }^{3}$ however, this sum does not translate into the actual number of potential opinion-providers. Many of these persons are recorded on at least several such lists, with some of them being registered on all the possible court lists in Poland. Unfortunately, this situation creates the danger that an expert who has been dismissed from this function in one region due to - among other things - improper performance of their duties ${ }^{4}$ will be appointed in another region.

Despite such a rich judicial offer, the trial body selecting the best analysis provider may face a difficult task. The speciality most frequently declared by the persons recorded on the court list is handwriting analysis (identifying and identification analysis, which is aimed at identifying the personal background of the executor and/or the author of the graphic recording, or the circumstances of its preparation). On the contrary, few people declare their ability to carry out technical or linguistic analyses of documents on the basis of the contested recordings. Rare are those experts who carry out comprehensive studies, such as handwriting and technical analyses.

An important problem related to the information content of said lists is the inability of the Appointing authority to actually verify a candidate's qualifications as an expert, i.e. their educational background, employment history, professional experience and the quality of drafted opinions or, finally, whether the duties ari-

Klinika Prawa "Niewinność", ”, Helsińska Fundacja Praw Człowieka [Helsinki Foundation for Human Rights], Warszawa 2007; Ł. Chojniak, Ł. Wiśniewski, Przyczyny niestusznych skazań w Polsce, Warszawa 2012.

2 Article 193 and 194 of the Polish Code of Criminal Proceedings Act, Journal of Laws 1997, item 555, as amended (Kodeks postępowania karnego, Dz.U. 1997, Nr 89, p. 555 z późn. zmianami).

3 In 1994, 69 were registered on the court list in the field of documents examination, Communication of 10 October 1994 on the register of court experts, Dz.Urz.MS.1994.5.30. (Komunikat z dnia 10 października 1994 roku w sprawie wykazu biegłych sądowych, Dz.Urz.MS.1994.5.30).

${ }^{4}$ Ordinance of the Minister of Justice of 24 January 2005 on court experts, Journal of Laws 2005, no. 15, item 133 (Rozporządzenie Ministra Sprawiedliwości z 24 stycznia 2005 roku w sprawie biegłych sądowych, Dz.U. 2005, Nr 15 p. 133). 
sing from the function served are carried out on time. The available data include only the first name, surname, business address, speciality, which is basically detailed by the experts themselves, and the duration of the term of office. Unfortunately, such a limited scope of information results in the need for further inquiries, or even in bad choices made by the opinion-making entity.

In order to avoid such a danger, trial bodies often use an unofficial ranking of experts who are reliable in their opinion, while the criteria for this reliability are defined in various and not always appropriate ways, such as short deadlines and low costs of opinion-giving activities, ${ }^{5}$ rather than the reliability of work.

An additional problem generating difficulties in the proper selection of the opinion-provider is also an inconsistent and arbitrary construction of court lists, also in terms of documents examination. The conclusion that emerged from their analysis was the lack of consistency in the structure of these lists in the respective 45 court regions. This is facilitated by the legal regulations in force, contained in the Ordinance of the Minister of Justice on court experts of 2005, which are unfortunately very general and allow for such arbitrariness. ${ }^{6}$ Pursuant to the provisions of paragraph 10 of this legislative act, the lists of experts shall be maintained in accordance with the determined templates. The problem is that no such template exists, which is why the authors of individual court lists use different names for the examination of written documents, which are not always correct and clear. Some of them include terminology derived from the outdated, yet still applicable, Communication by the Ministry of Justice on the list of court experts, dating back to as early as $1994,{ }^{7}$ which contains court experts appointed for occasional or rare specialities. ${ }^{8}$

The said Communication distinguishes between two types of written documents examination: forensic documents examination (graphoscopy) and handwriting analysis (graphology). This terminology itself can already be questioned. The notion of graphoscopy, explained as handwriting studies, is not recommend$\mathrm{ed}^{9}$ by the scientific and specialist community, while the notion of graphology has no attribute of acuity, as in Poland, it is used to mean at least three different

5 M. Janocha, "Konieczność ujednolicenia systemu kształcenia biegłych w zakresie pismoznawstwa", [in:] Zagadnienia dowodu z ekspertyzy dokumentów, ed. R. Cieśla, Wrocław 2017, p. 198.

${ }^{6}$ Ordinances of the Minister of Justice on court experts of 2005, Journal of Laws 2005, no. 15, p. 133 (Rozporządzenia Ministra Sprawiedliwości w sprawie biegłych sądowych z 2005 r., Dz.U. 2005, Nr 15 p. 133).

7 Communication of 10 October 1994 on the register of court experts, Dz.Urz.MS.1994.5.30. Out of 1413 persons registered in the list in 100 specialities, 69 are potential experts in the field of written documents analysis (Komunikat z dnia 10 października 1994 roku w sprawie wykazu biegłych sądowych, Dz.Urz.MS.1994.5.30).

8 Biegly w postępowaniu cywilnymi karnym. Komentarz praktyczny z orzecznictwem. Wzory pism procesowych i orzeczeń, ed. K. Flaga-Gieruszyńska, Warszawa 2017, p. 254.

9 Słownik terminów pismoznawczych [Dictionary of handwriting terms], http://prawouamstp.home.amu.edu.pl/ (accessed: 18.10.2019). 
things. ${ }^{10}$ The source of such confusion is the lack of terminological consistency in the field of handwriting analysis, which appears in textbooks, scientific publications in forensic sciences, ${ }^{11}$ as well as in the opinion-giving practice. Unfortunately, this may translate into issues arising from the selection of an expert specialised in the relevant field of written documents examination by the trial body.

The list maintained at Regional Courts in Torun and Nowy Sącz is built on the basis of the presented classification of documents examination. Other court lists contain different classifications.

For example, the website of the Regional Court in Wroclaw offers separate sections provided in alphabetical order, concerning documents examination, such as: graphology and forensics, with the latter one subdivided into forensic handwriting analysis and documents examination, classical documents examination and technical documents examination. An additional column provides detailed information about the experts' speciality. Said arrangement results in the same types of examination specialities being repeated in the fields of graphology and forensics. Moreover, the surnames of certain persons are also repeated. In addition, the experts use different terminology to describe the same types of analyses, which creates chaos. For example, one of the persons named their specialities as follows: forensic, classical, psychological handwriting analysis, documents examination, handwriting pathology analysis, linguistic forensics, psychographology, and graphology. ${ }^{12}$

A more transparent form could include a general section called Forensic examination of written documents, and it would distinguish three types of document examinations, i.e. classical, technical and linguistic examination. The first one would include handwriting analyses (of continuous records and signatures, typescripts, seals, stamps) of identification and identifying nature; the second one would concern the verification of authenticity of documents based on the characteristic features of the substrate, the covering agent, the writing agent, the security features, specification of document-making techniques, identification of printing devices, examination of destroyed documents, disclosure of impressed handwriting and identification of the age of documents $;{ }^{13}$ and the third one would focus on the analysis of content-related and linguistic fingerprint.

10 As documents examination (comparative, identifying, technical), as identifying analysis, and finally - as an ability to determine the person's character, skills and likings based on a graphism - in the latter meaning, it relies on intuition, cf. Słownik terminów pismoznawczych, http:// prawouam-stp.home.amu.edu.pl/ (accessed: 18.10.2019); A. Koziczak, Metody pomiarowe w badaniach pismoznawczych, Kraków 1997, pp. 63-64.

11 Cf. e.g. Z. Czeczot, T. Tomaszewski, Kryminalistyka ogólna, Torun 1996; R. Ponikowski, "Sposób i forma przedstawienia opinii przez biegłego w postępowaniu sądowym", [in:] Problematyka dowodu z ekspertyz dokumentów, ed. Z. Kegel, Wrocław 2002, p. 908; E. Gruza, M. Goc, J. Moszczyński, Kryminalistyka, czyli rzecz o metodach śledczych, Warszawa 2008, pp. 403-404.

$12 \mathrm{http} / /$ www.wroclaw.so.gov.pl/index.php?option=com_content\&view=article\&id=104 \&Itemid=123 (accessed: 18.10.2019).

13 E. Gruza, M. Goc, J. Moszczyński, op. cit., pp. 362-363. 
The presented state of affairs is an unquestionable reflection of the problem, which has been raised for a long time, namely the lack of a uniform and universally available methodology for handwriting analysis, especially with regard to the graphical layer of a document, ${ }^{14}$ which defines their procedure, nomenclature ${ }^{15}$ and the rules for evaluating the graphical features of recordings. Developing such a methodology is a very difficult task, mainly due to the subjective nature of the evaluations carried out as part of handwriting analysis. ${ }^{16}$

The problem of selecting the best expert from the court list at the level of the trial body conducting certain legal proceedings is also caused by the lack of proper systemic regulations concerning the procedure of qualifying candidates for registration in the lists of court experts. Although there is a presumption of the best qualifications for a person already registered, in many cases this presumption is rebuttable. The reasons for this situation can be explained by:

1. Inability to verify the theoretical background and practical experience of a candidate applying for registration in the list of court experts in the field of documents examination, e.g. by way of an examination passed before a specially appointed board of experts in this field of study.

2. The lack of standards for a uniform system of training experts in the field of documents examination.

As far as the former reason is concerned, verification of the candidate's theoretical and practical level of above-average special expertise, as set out in the Ordinance on court experts, ${ }^{17}$ is carried out on the basis of documents and may also be demonstrated by means of other evidence. The methods developed in practice for verifying these criteria differ throughout Poland due to the lack of detailed guidelines laid down by the legislator. For example, in the practice of the Regional Court in Poznan, the level and type of the candidate's professional education, as well as their supplementary education, are taken into account. Their education is checked for compliance with the field of study in which the candidates would issue their opinions. For handwriting analysis, an adequate professional education

14 Cf. M. Leśniak, Wartość dowodowa opinii pismoznawczej, Pińczów 2012, p. 236. The literature provides only schematic overviews of examination procedures for handwriting expert studies, cf. M. Kulicki, V. Kwiatkowska-Wójcikiewicz, L. Stępka, Kryminalistyka. Wybrane zagadnienia teorii i praktyki śledczo-sąowej, Toruń 2009, pp. 432-440; M. Goc, Wspótczesny model ekspertyzy pismoznawczej. Wykorzystanie nowych metod i technik badawczych, Warsaw-Szczecin 2015, pp. $156-164$.

15 Cf. R. Ponikowski, op. cit., p. 908. The first attempt to standardise the terminology was started by the works on the dictionary of handwriting terms, http://prawouam-stp.home.amu.edu.pl/ (accessed: 18.10. 2019).

16 J. Moszczyński, Subiektywizm w badaniach kryminalistycznych. Przyczyny i zakres stosowania subiektywnych ocen w wybranych metodach identyfikacji człowieka, Olsztyn 2011, pp. 126-139.

$17 \S 12$ (2) of the Ordinance on court experts of 24 January 2005, Journal of Laws 2005, no. 15 p. 133 (§ 12 ust. 2 rozporządzenia w sprawie biegłych sądowych z 24 stycznia 2005 roku, Dz.U. 2005, Nr 15 p. 133). 
is considered to be the relevant legal, philological and linguistic, or psychological background. It also happens that, in order to assess a candidate's qualifications, the Presidents of the Regional Courts are assisted by consultants, i.e. persons who are unquestionable authorities in a given field of knowledge. ${ }^{18}$

Verification of a candidate's practical preparedness is more complicated, as Presidents of the Regional Courts are not in a position to subject the applicant for registration in the court list to some kind of a practical examination. In this respect, they may rely mainly on documents attesting to the candidate's practical opinion-giving experience. Therefore, these findings are made on the basis of, for example, a certificate authorising the candidate to issue an opinion at forensic police laboratories, a positive written interview conducted by the authorities in charge of pre-trial proceedings, and at courts (e.g. in the case of an expert previously appointed on an ad hoc basis), a written recommendation letter of the persons conducting pre-trial or court proceedings, a written opinion issued by an association of surveyors in a given speciality, ${ }^{19}$ or the entity providing the training which has been completed by the candidate.

The above problem is indirectly related to the lack of educational standards for future experts in documents examination in Poland. It is worth noting that the postulate to design a uniform and comprehensive educational system in this opinion-giving area has been put forward for a long time. At present, candidates applying for an entry on the court list demonstrate their relevant theoretical background and practical experience on the basis of documents attesting to the completion of various trainings, courses or postgraduate studies. They are organised by state institutions, such as forensic police laboratories, the Polish Security Printing Works (PWPW) for verification of the authenticity of documents, the Border Guard, a few public universities, and private universities, as well as private institutions which pursue business activities in the field of documents examination. The curriculum offer of these forms of education varies a lot; however, this does not ensure an adequate practical dimension of education, and their duration is very short in some cases. Nevertheless, it is obvious that an expert should be distinguished by long-term practice which is essential for the acquisition of experience. The providers of various forms of education, with few exceptions, usually point out that the knowledge gained during the offered trainings is not sufficient for opinion-giving activities in legal proceedings; thus, the documents which certify the completion of such trainings should not be the only basis for registration in the list of court experts. ${ }^{20}$ On the contrary, they can be useful in order to com-

18 M. Hrehorowicz, "Kwalifikacje biegłych sądowych z dziedziny kryminalistyki oraz sposób ich weryfikacji” [in:] Zagadnienia z dowodu z ekspertyzy dokumentów, ed. R. Cieśla, Wrocław 2017, p. 170.

19 Ibidem, p. 172.

20 M. Janocha, op. cit., pp. 193-195. 
plement the qualifications acquired earlier, which is why they are often used by persons already registered in the list. ${ }^{21}$

According to the academic literature, a good solution for persons willing to gain expertise in documents examination would be to receive professional training under the supervision of an experienced expert; however, this training process is not frequently practised in the Polish reality, as, for various reasons, experts are reluctant to share their experience. In addition, it could be a problem to select the right teacher and verify his or her competencies. ${ }^{22}$ Such a system of education would therefore escape scrutiny by the decision-making body, which verifies the preparedness of a candidate for a court expert.

According to the representatives of scientific and expert community, the best option would be an institutionalised form of education for documents examination experts. The expert training system used years ago at the Department of Forensic Science of the General Headquarters of the then Citizens' Militia, with the School of Experts, including the Department of Documents Examination operating within its structure, is referred to as a model solution. It provided a five-year education period split into two stages, each of them ending with an examination. The training offered theoretical and practical courses. If successfully completed, it served as a basis to obtain the title of an independent police expert. ${ }^{23}$

The modern system of police training governed by Order No. 3 of the Police Commander-in-Chief of January 17, 2014 on the rights to issue opinions and to perform activities at police forensic laboratories is not that intense and long. Firstly, it provides for a qualification procedure (the candidate must have a relevant university degree and appropriate predisposition to perform the activities of an expert), and then a 24-month training period, during which a participant takes part in a specialist course in a given field of forensic technique, develops a certain number of opinions regarding the training speciality, participates in the inspection of the sites of incidents and autopsies, in court trials with the participation of experts, and undergoes an internship at police forensic laboratories. The candidate undergoes an interim evaluation every six months, and then a final evaluation. ${ }^{24}$ Upon completion of the training, the graduate obtains a licence to work as an expert. ${ }^{25}$

21 Ibidem, p. 195.

22 Ibidem, p. 193.

23 A. Buczek, "Standaryzacja kształcenia ekspertów z zakresu badań identyfikacyjnych pisma jako podstawa wpisu na listę biegłych sądowych", [in:] Pozycja i rola biegłego w polskim systemie prawnym, ed. B. Lewandowski, Warszawa 2016, p. 191.

24 Order No. 3 of the Police Commander-in-Chief of 17 January 2014 on the rights to issue opinions and to perform activities at forensic police laboratories, Journal of Laws, item 7, as amended (Zarządzenie nr 3 Komendanta Głównego Policji z dnia 17 stycznia 2014 roku w sprawie uprawnień do wydawania opinii oraz wykonywania czynności w policyjnych laboratoriach kryminalistycznych, Dz. Urz. KGP poz. 7 ze zmianami).

25 M. Kowalik, M. Włudyka, "Studium pracy biegłego z zakresu pismoznawstwa", [in:] Zagadnienia z dowodu z ekspertyzy dokumentów, ed. R. Cieśla, Wrocław 2017, pp. 239-240; Order 
It is now proposed to set up a five-year study programme, which will end with a state examination, and to develop a qualification system for candidates, followed by an interview. Two-thirds of the training time should be devoted to practical classes with the use of specific cases in the field of handwriting analysis and to work with state-of-the-art equipment. The studies should be divided into two specialities, with the former one covering the issues of handwriting analysis, and the latter one concerning technical examination of documents. On the contrary, the theoretical course would include the acquisition of current knowledge in the field of e.g. psychology, linguistics, physiology, physics, chemistry and computer science. ${ }^{26}$

To ensure the success of such an undertaking, it would be necessary to frame and regulate the requirements for the teaching staff, i.e. the training and professional development system designed for them, and to develop a curriculum, set up technical facilities, and arrange professional internships for students. ${ }^{27}$

An alternative proposed solution is access to a professional examination consisting of the theoretical and practical part; during the latter, the candidate's task would be to perform a trial examination of documents. It is doubtful, however, that the limited timeframe of such an examination may provide an adequate assessment of the examinee's preparedness level. ${ }^{28}$

Unfortunately, all the solution concepts, as briefly outlined above, concerning the development of a uniform methodology for handwriting analysis and the setup of a training system for experts in the field of documents examination, remain nothing more than postulates.

In addition to the experts registered in court lists and the available option of appointing - on an ad hoc basis - persons known to have special expertise in a particular field of knowledge ${ }^{29}$ to give an opinion, the trial body may also request an opinion from a scientific, specialist or scientific-specialist institution. In this case, the decision-maker is not in a position to make a choice on the basis of a list of such entities. Since, on the expert market, there is a multitude of offers for the performance of documents examination by public and private entities for the purposes of legal proceedings, it may also prove difficult to select an appropriate opinion-provider. In this case, however, an aspect facilitating the designation of the best provider of top-quality analysis is that the provider holds an accreditation certificate, awarded by an authorised national body, to carry out specific

No. 3 of the Police Commander-in-Chief of 17 January 2014 on the rights to issue opinions and to perform activities at forensic police laboratories, Journal of Laws Dz. Urz. KGP, item 7, as amended.

26 M. Kowalik, M. Włudyka, op. cit., pp. 191-192.

${ }^{27}$ Ibidem, p. 192; M. Janocha, op. cit., p. 199.

28 M. Janocha, op. cit., p. 198.

29 Article 193, article 195, the Polish Code of Criminal Proceedings Act, Journal of Laws 1997, no. 89, item 555, as amended [art. 193, art. 195, ustawa Kodeks postępowania karnego, Dz.U. 1997, Nr 89, p. 555 z późn. zmianami]. 
activities, such as analyses. ${ }^{30}$ For example, the certificates of the Polish Centre for Accreditation have been awarded to police forensic laboratories and the Institute of Forensic Research, as well as to other laboratories including private ones.

The problems specified above, related to the functioning of the expert model in Poland, have been and are the reason for phrasing postulates to improve the quality of opinion-giving and to increase the level of trust in the justice system. The actual works aimed at regulating the institution of a court expert and their legal status has been carried out by the Ministry of Justice since 2005, and are continued to the present day. Over this nearly 15-year period, assumptions for the draft law on court experts were proposed, and draft laws were prepared on their basis, with some of them being submitted for public consultation; one of them was even referred for proceedings by the Sejm, ${ }^{31}$ but to no avail.

An important action in terms of pointing out the direction of changes in relation to the current opinion-giving model was the audit carried out in 2014 and 2015 by the Supreme Audit Office. Its outcome was extensive information contained in the document issued by that authority under the title: The functioning of experts in the justice system, which first of all indicates the reasons for the inspection procedures that can be obviously referred to opinion-giving activities in the field of documents examination. Among other things, the list contains:

1. An increasing participation and role of experts in the conducted legal proceedings, due to the courts being required to resolve complex issues which demand specialist knowledge broader than before.

2. Growing expenses of the State Treasury incurred in connection with the appointment of experts.

3. Cases of experts' incompetence resulting in miscarriages of justice.

4. Prolixity of court proceedings caused by the lengthy waiting time for trial bodies to receive an expert opinion.

5. The current experts functioning model criticised by legal and scientific communities, associations and organisations associating experts of various specialities. ${ }^{32}$

30 The Act of 13 April 2016 on conformity assessment and market surveillance systems, Journal of Laws 2019, item 544 (Ustawa z dnia 13 kwietnia 2016 roku o systemach oceny zgodności i nadzoru rynku, Dz.U. 2019 poz. 544).

31 Drafts laws of 2006, 2009, 2014. In March 2014, the Council of Ministers developed draft assumptions for the act on court experts, and subsequently in October 2014, the Government Legislation Centre (Rządowe Centrum Legislacji), in cooperation with the Minister of Justice, presented a draft law on court experts.

32 Information on the results of the inspection conducted by Nadrzędna Izba Kontroli, NIK, Departament Porządku I Bezpieczeństwa Wewnętrznego [Supreme Control Chamber, Department of Order and Internal Security] Funkcjonowanie biegłych $w$ wymiarze sprawiedliwości, Warszawa 2015, p. 7, https://www.nik.gov.pl/aktualnosci/nik-o-bieglych-w-wymiarze-sprawiedliwosci.html (accessed: 26.10.2019). 
As a result of the audit, the Supreme Audit Office found that the current experts functioning model:

1. Does not guarantee the appointment of persons who ensure the highest quality of the opinions issued and their on time delivery for the purposes of legal proceedings.

2. This model does not provide the grounds for an adequate verification of an expert candidate's competencies in terms of the procedure for registration in the list of court experts and, consequently, when appointing an expert in a specific case.

3 . The changes proposed in the draft law on court experts of 2014 are insufficient and do not ensure an effective functioning of the expert model in the justice system. ${ }^{33}$

The scientific assessment of the current expert status has also been analysed in various research projects, including those undertaken at the request of the Supreme Audit Office, which comprise, among others:

1. Strengthening the Polish Justice System (2008), ${ }^{34}$

2. Court experts in Poland, initiated by the Helsinki Foundation for Human Rights (2014), ${ }^{35}$

3. Experts functioning models in the EU countries (2015), ${ }^{36}$

4. Evaluation of the competencies of court experts. Expectations and recommendations (2015). ${ }^{37}$

The implementation of these projects resulted in the postulates being elaborated, which - once implemented - would ensure the development of a new, efficient opinion-giving system. They were partly reflected in the new draft law on court experts, prepared by the Ministry of Justice, ${ }^{38}$ which at the turn of 2018 and 2019 was submitted for analysis and evaluation by the academic community. The basic changes provided for in the draft assumed that:

33 Information on the results of the inspection conducted by the Supreme Control Chamber, Department of Order and Internal Security.

${ }^{34} \mathrm{https}: / / 1 \mathrm{kns} . \mathrm{pl} / \mathrm{wp}-\mathrm{content} /$ uploads/2014/04/System-bieg\%C5\%82ych-s\%C4\%85dowychw-Polsce-i-innych-krajach.pdf (accessed: 18.10.2019).

35 https://www.hfhr.pl/raport-biegli-sadowi-w-polsce/ (accessed: 18.10.2019).

36 Expert opinion carried out at the request of the Supreme Control Chamber, drafted by M. Tomaszewska-Michalak, Modele funkcjonowania instytucji bieglego $w$ wybranych krajach Unii Europejskiej w kontekście ich wplywu na sprawność wymiaru sprawiedliwości, 2015, [in:] Information on the results of the NIK inspection entitled Funkcjonowanie biegtych $w$ wymiarze sprawiedliwości, Department of Order and Internal Security, Warszawa 2015, https://www.nik.gov.pl/ aktualnosci/nik-o-bieglych-w-wymiarze-sprawiedliwosci.html, p. 14 (accessed: 26.10.2019).

$37 \mathrm{http} / / /$ forensicwatch.pl/web/pliki/baza-wiedzy/Opracowania/Ocena-Kompetencji-Bieg lych-Sadowych.pdf (accessed: 18.10.2019).

38 Draft law developed by the Legislative Department for Criminal Law at the Ministry of Justice which constitutes an element of conceptual works on the new regulations regarding the functioning of court experts. As noted in the covering letter of 21 December 2018, addressed to the representatives of the academic community, also other concepts of legal solutions are taken into account. 
1. Experts would have a right to protection, vested in a public official.

2. The Minister of Justice would maintain a single list of experts and a register of scientific or specialist institutions.

3. The basis for an entry on the list or register would be a certificate granted by the head of the Institute of Forensic Research, after an opinion issued by the locally competent Voivodeship Police Commander or the Capital City Police Commander - where necessary - in consultation with the Opinion-Giving Standards Committee, has been obtained.

4. Age limits for court experts would be applied. The function of an expert could be performed by a person under 70 years of age.

5. The function of an expert shall be open to a person who has theoretical special expertise and at least five years of experience in the field in which he or she intends to perform the expert activities.

6. The expert's fees for drawing up the opinion would be paid in phases. Part of the fees would be paid where the expert's opinion would prove useful in the conducted proceedings and would have impact on the resolution of the trial body.

This draft did not receive a positive assessment, since its provisions do not comply with the legal regulations of the Polish Code of Criminal Proceedings as regards the restriction of the free choice of an expert by the trial body, due to the lack of clear rules on the procedure for certification of experts and their remuneration. The entity that would do this is a representative of an institution that also provides opinions in legal proceedings, and apart from this, it operates within the structures of the Ministry of Justice. It is therefore difficult to ensure its impartiality in these circumstances.

The above brief analysis of the work aimed at creating a new system of expert opinion-giving services for the benefit of law enforcement agencies and the justice system shows that its creation is not an easy undertaking and that the level of the related work progress is not satisfactory.

The only new legal solution aimed ${ }^{39}$ at ensuring the proper functioning of the justice system, free from costly, protracted legal proceedings and opinions issued by unreliable experts, are the amendments to the Polish Criminal Code introduced in 2016, which reinforce the experts' liability for breach of order, increasing the criminal sanctions for presenting a false opinion, and introducing a privileged form of this act as an unintentional offence. In view of these legal regulations, fears are expressed that in the absence of a uniform, comprehensive regulation of the expert status by a legal act at the statutory level, they may result in experienced experts withdrawing from the opinion-giving practice.

39 Kodeks karny. Komentarz, eds. A. Grześkowiak, K. Wiak, https://sip.legalis.pl (accessed: 28.10.2019). 


\section{REFERENCES}

Buczek A., "Standaryzacja kształcenia ekspertów z zakresu badań identyfikacyjnych pisma jako podstawa wpisu na listę biegłych sądowych", [in:] Pozycja i rola biegłego w polskim systemie prawnym, ed. B. Lewandowski, Warszawa 2016.

Chojniak Ł., Wiśniewski Ł., Przyczyny niestusznych skazań w Polsce, Warszawa 2012.

Czeczot Z., Tomaszewski T., Kryminalistyka ogólna, Toruń 1996.

Biegly w postępowaniu cywilnymi karnym. Komentarz praktyczny z orzecznictwem. Wzory pism procesowych i orzeczeń, ed. K. Flaga-Gieruszyńska, Warszawa 2017.

Goc M., Wspótczesny model ekspertyzy pismoznawczej. Wykorzystanie nowych metod i technik badawczych, Warszawa-Szczecin 2015.

Gruza E., Goc M., Moszczyński J., Kryminalistyka, czyli rzecz o metodach śledczych, Warszawa 2008.

Hrehorowicz M., "Kwalifikacje biegłych sądowych z dziedziny kryminalistyki oraz sposób ich weryfikacji”, [in:] Zagadnienia z dowodu z ekspertyzy dokumentów, ed. R. Cieśla, Wrocław 2017.

Janocha M., "Konieczność ujednolicenia systemu kształcenia biegłych w zakresie pismoznawstwa", [in:] Zagadnienia dowodu z ekspertyzy dokumentów, ed. R. Cieśla, Wrocław 2017.

Juchacz W., Pomytki sądowe w sprawach o zabójstwa. Studium karno-procesowe, Bydgoszcz 2016.

Klinika Prawa „Niewinność”, Helsińska Fundacja Praw Człowieka, Warszawa 2007.

Kodeks karny. Komentarz, eds. A. Grześkowiak, K. Wiak, https://sip.legalis.pl (accessed: 28.10.2019).

Komunikat z dnia 10 października 1994 roku w sprawie wykazu biegłych sądowych, Dz.Urz. MS.1994.5.30.

Kowalik M., Włudyka M., "Studium pracy biegłego z zakresu pismoznawstwa”, [in:] Zagadnienia $z$ dowodu z ekspertyzy dokumentów, ed. R. Cieśla, Wrocław 2017, pp. 239-240.

Koziczak A., Metody pomiarowe w badaniach pismoznawczych, Kraków 1997.

Kulicki M., Kwiatkowska-Wójcikiewicz V., Stępka L., Kryminalistyka. Wybrane zagadnienia teorii i praktyki śledczo-sadowej, Toruń 2009.

M. Leśniak, Wartość dowodowa opinii pismoznawczej, Pińczów 2012.

Mazur O., "Niesłuszne skazania w Polsce w opinii prokuratorów i policjantów", Palestra 2012, no. 3-4.

Moszczyński J., Subiektywizm w badaniach kryminalistycznych. Przyczyny i zakres stosowania subiektywnych ocen w wybranych metodach identyfikacji człowieka, Olsztyn 2011.

Ponikowski R., "Sposób i forma przedstawienia opinii przez biegłego w postępowaniu sądowym", [in:] Problematyka dowodu z ekspertyz dokumentów, ed. Z. Kegel, Wrocław 2002.

Słownik terminów pismoznawczych, http://prawouam-stp.home.amu.edu.pl/.

Sowa A., "Przyczyny pomyłek sądowych", Palestra 2002, no. 1.

Tomaszewska-Michalak M., "Modele funkcjonowania instytucji biegłego w wybranych krajach Unii Europejskiej w kontekście ich wpływu na sprawność wymiaru sprawiedliwości”, [in:] Informacja o wynikach kontroli NIK Funkcjonowanie biegtych $w$ wymiarze sprawiedliwości, Departament Porządku I Bezpieczeństwa Wewnętrznego, Warszawa 2015, https://www.nik.gov. pl/aktualnosci/nik-o-bieglych-w-wymiarze-sprawiedliwosci.html, (accessed: 26.10.2019).

Tomaszewska-Michalik M, "Możliwości oceny kompetencji biegłego-jak sobie radzić z tym problemem”, [in:] Zagadnienia dowodu z ekspertyzy dokumentów, ed. R. Cieśla, Wrocław 2017.

Widacki J., Dudzińska A., "Pomyłki sądowe. Skazania osób niewinnych przez sądy w Polsce”, $P a$ lestra 2007, no. 11-12. 